\title{
Spatiotemporal transformation of dissolved organic matter along an alpine stream flow path on the Qinghai-Tibet Plateau: importance of source and permafrost degradation
}

\author{
Yinghui Wang ${ }^{1,2}$, Robert G. M. Spencer ${ }^{3}$, David C. Podgorski ${ }^{4}$, Anne M. Kellerman ${ }^{3}$, Harunur Rashid ${ }^{1}$, Phoebe Zito ${ }^{4}$, \\ Wenjie Xiao ${ }^{2}$, Dandan Wei ${ }^{1}$, Yuanhe Yang ${ }^{5}$, and Yunping Xu${ }^{1}$ \\ ${ }^{1}$ Shanghai Engineering Research Center of Hadal Science and Technology, College of Marine Sciences, Shanghai Ocean \\ University, Shanghai 201306, China \\ ${ }^{2}$ Key Laboratory for Earth Surface Processes of the Ministry of Education, College of Urban and Environmental Sciences, \\ Peking University, Beijing 100871, China \\ ${ }^{3}$ National High Magnetic Field Laboratory Geochemistry Group and Department of Earth, Ocean, and Atmospheric Science, \\ Florida State University, Tallahassee, FL 32306, USA \\ ${ }^{4}$ Pontchartrain Institute for Environmental Sciences, Department of Chemistry, University of New Orleans, \\ New Orleans, LA 70148, USA \\ ${ }^{5}$ State Key Laboratory of Vegetation and Environmental Change, Institute of Botany, Chinese Academy \\ of Sciences, Beijing 100093, China
}

Correspondence: Yunping Xu (ypxu@ shou.edu.cn)

Received: 10 April 2018 - Discussion started: 28 May 2018

Revised: 24 October 2018 - Accepted: 26 October 2018 - Published: 8 November 2018

\begin{abstract}
The Qinghai-Tibet Plateau (QTP) accounts for approximately $70 \%$ of global alpine permafrost and is an area sensitive to climate change. The thawing and mobilization of ice-rich and organic-carbon-rich permafrost impact hydrologic conditions and biogeochemical processes on the QTP. Despite numerous studies of Arctic permafrost, there are no reports to date for the molecular-level in-stream processing of permafrost-derived dissolved organic matter (DOM) on the QTP. In this study, we examine temporal and spatial changes of DOM along an alpine stream (3850-3207 m above sea level) by Fourier transform ion cyclotron resonance mass spectrometry (FT-ICR MS), accelerator mass spectrometry (AMS) and UV-visible spectroscopy. Compared to downstream sites, dissolved organic matter (DOM) at the headstream site exhibited older radiocarbon age, higher mean molecular weight, higher aromaticity and fewer highly unsaturated compounds. At the molecular level, 6409 and 1345 formulas were identified as unique to the active layer (AL) leachate and permafrost layer (PL) leachate, respectively. Comparing permafrost leachates to the downstream site, $59 \%$ of AL-specific formulas and $90 \%$ of PL-specific formulas were degraded, likely a result of rapid in-stream
\end{abstract}

degradation of permafrost-derived DOM. From peak discharge in the summer to low flow in late autumn, the DOC concentration at the headstream site decreased from 13.9 to $10.2 \mathrm{mg} \mathrm{L}^{-1}$, while the ${ }^{14} \mathrm{C}$ age increased from 745 to 1560 years before present (BP), reflecting an increase in the relative contribution of deep permafrost carbon due to the effect of changing hydrological conditions over the course of the summer on the DOM source (AL vs. PL). Our study thus demonstrates that hydrological conditions impact the mobilization of permafrost carbon in an alpine fluvial network, the signature of which is quickly lost through in-stream mineralization and transformation.

\section{Introduction}

The amount of organic carbon stored in permafrost is roughly twice as much as that in the atmosphere and represents the largest component of the terrestrial carbon pool (Zimov et al., 2006; Tarnocai et al., 2009). Accelerated climate warming has led to a succession of changes associated with permafrost thaw, whereby water once frozen in permafrost soils 
has changed watershed hydrology, topography and ecosystem biogeochemistry (Frey and Smith, 2005; Abbott et al., 2015; Vonk et al., 2015). When permafrost-derived organic carbon enters aquatic systems, it can be rapidly mineralized and transformed by microbes and light (Cory et al., 2014; Drake et al., 2015; Vonk et al., 2015). Therefore, the mobilization of organic carbon from permafrost soils where it has been relatively stable for thousands of years into dissolved carbon could increase greenhouse gas emissions (Cory et al., 2013; Vonk et al., 2013; Mann et al., 2015; Ward and Cory, 2016; Selvam et al., 2017) and exacerbate climate warming via a positive feedback loop (Koven et al., 2011; Schuur et al., 2015).

The seasonal thawing-freezing cycle of permafrost soils could change hydrologic conditions and restrict source water contributions to river flow, leading to variability in the flux and the chemical composition of dissolved organic matter (DOM) in permafrost-impacted watersheds (Petrone et al., 2006; Laudon et al., 2011). DOM in the Yukon River exhibits seasonal changes in aromaticity, molecular weight, ${ }^{14} \mathrm{C}$ age and biodegradability (Striegl et al., 2007; Spencer et al., 2008; Wickland et al., 2012; O'Donnell et al., 2014). Since the persistence of DOM in aquatic systems is related to its chemical composition (Kellerman et al., 2015, 2018), detailed chemical characterization of DOM is essential to illustrate the environmental behavior and the fate of seasonally exported permafrost organic carbon.

The Qinghai-Tibet Plateau (QTP), the world's largest and highest plateau, plays a critical role in the evolution of the Asian monsoon (Sato and Kimura, 2007; Wu et al., 2007) and supplies water to several large rivers such as the Yangtze River, Yellow River and Yarlung Tsangpo (Yao et al., 2007; Kang et al., 2010). As a climate-sensitive region, the QTP has experienced significant warming since the 1950s (Qiu, 2008), with the mean annual air temperature rising at a rate of $0.36^{\circ} \mathrm{C}$ per decade from 1961 to 2007 (Wang et al., 2008). Consequently, permafrost soils on the QTP have begun to thaw and collapse, causing abundant organic carbon loss from in situ degradation (Mu et al., 2016) and relocation (e.g., selective leaching in different soil layers; Wang et al., 2018). However, compared with an abundance of studies on Arctic permafrost, biogeochemical studies on QTP permafrost are scant. This results in a limited understanding of the permafrost carbon cycle as a whole since the QTP represents nearly $10 \%$ of global permafrost; furthermore, the QTP differs from the Arctic in altitude, climate and hydrology (Bockheim and Munroe, 2014).

Here, we conducted a study on the spatial and temporal change of permafrost-derived DOM on the northeastern QTP. We applied multiple analytical techniques including Fourier transform ion cyclotron resonance mass spectrometry (FTICR MS), accelerator mass spectrometry (AMS) radiocarbon analyses $\left({ }^{14} \mathrm{C}\right)$ and UV-visible optical spectroscopy. Our objective was twofold: (1) determine the dominant sources of alpine stream DOM on the QTP (active layer, AL, vs. per- mafrost layer, PL); and (2) trace the persistence and degradation of permafrost-derived DOM in an alpine fluvial network. This work represents the first step in characterizing in-stream removal and transformation processes of permafrost organic carbon at the molecular level on the QTP.

\section{Materials and methods}

\subsection{Study area and sampling}

Our study area is located in Gangcha County, north of Qinghai Lake. The climate is a typical plateau continental climate, characterized by extensive solar duration $(\sim 3000 \mathrm{~h}$ per year), long cold and dry winters and short cool and humid summers (Peng et al., 2015). During 2013-2016, January had the lowest average monthly temperature $\left(-11.82^{\circ} \mathrm{C}\right)$, while December had the lowest average monthly precipitation $(0.3 \mathrm{~mm})$. Meanwhile, the highest average monthly temperature and precipitation occurred in July $\left(11.66^{\circ} \mathrm{C}\right)$ and August $(124.67 \mathrm{~mm})$, respectively. These climate data are available at http://data.cma.cn (last access: 10 August 2017). The permafrost soil in the region was developed in the late Quaternary, and accumulated in a layer $>2 \mathrm{~m}$ thick in mountainous areas of the Gangcha County. Due to rapid climate warming on the QTP, the ice-rich permafrost has begun to thaw, and several thermo-erosion gullies formed a decade ago. In this study, we focused on a continuous system that starts with a thermo-erosion gully ( $>200 \mathrm{~m}$ long), which forms a stream that flows into Qinghai Lake, the largest lake in China with a surface area of ca. $4500 \mathrm{~km}^{2}$. Thawed permafrost slumping exposed soil profiles at the gully heads (ca. $3850 \mathrm{~m}$ above sea level; ma.s.l.); detailed description on the collapse can be found in Wang et al. (2018). The top $60 \mathrm{~cm}$ is AL that comprises abundant grass litter and roots, underlain by dark PL without visible plant debris. The maximal thaw depth reached $78 \mathrm{~cm}$ in August 2015 (i.e., thawing into the PL). Seasonal thaw of the entire AL and the upper PL allows for both vertical and lateral percolation of rainwater, which mobilizes large amounts of particulate and dissolved organic matter. The water in the gully flows southward across the hillslope before draining into Qinghai Lake, and the total length of the stream is around $40 \mathrm{~km}$ (Fig. 1).

Our fieldwork was conducted in the summer and autumn of 2015 and 2016. In 2015, a time series sampling campaign was conducted at the headstream (Q-1) from $1 \mathrm{Au}-$ gust, when the warm and humid climate caused the largest export of leachates, to 15 October, when the leaching ceased due to little precipitation and low temperature. On $1 \mathrm{Au}-$ gust of 2015 and 2016, AL and PL leachates were collected at depths of 60 and $220 \mathrm{~cm}$, respectively, at the gullies' head. 20 L HDPE carboys were cleaned with pure water, $0.1 \mathrm{~N}$ hydrochloric acid and pure water again prior to use. It typically took 2 days to gather $>15 \mathrm{~L}$ of leachate waters. After that, the leachate samples were immediately kept 


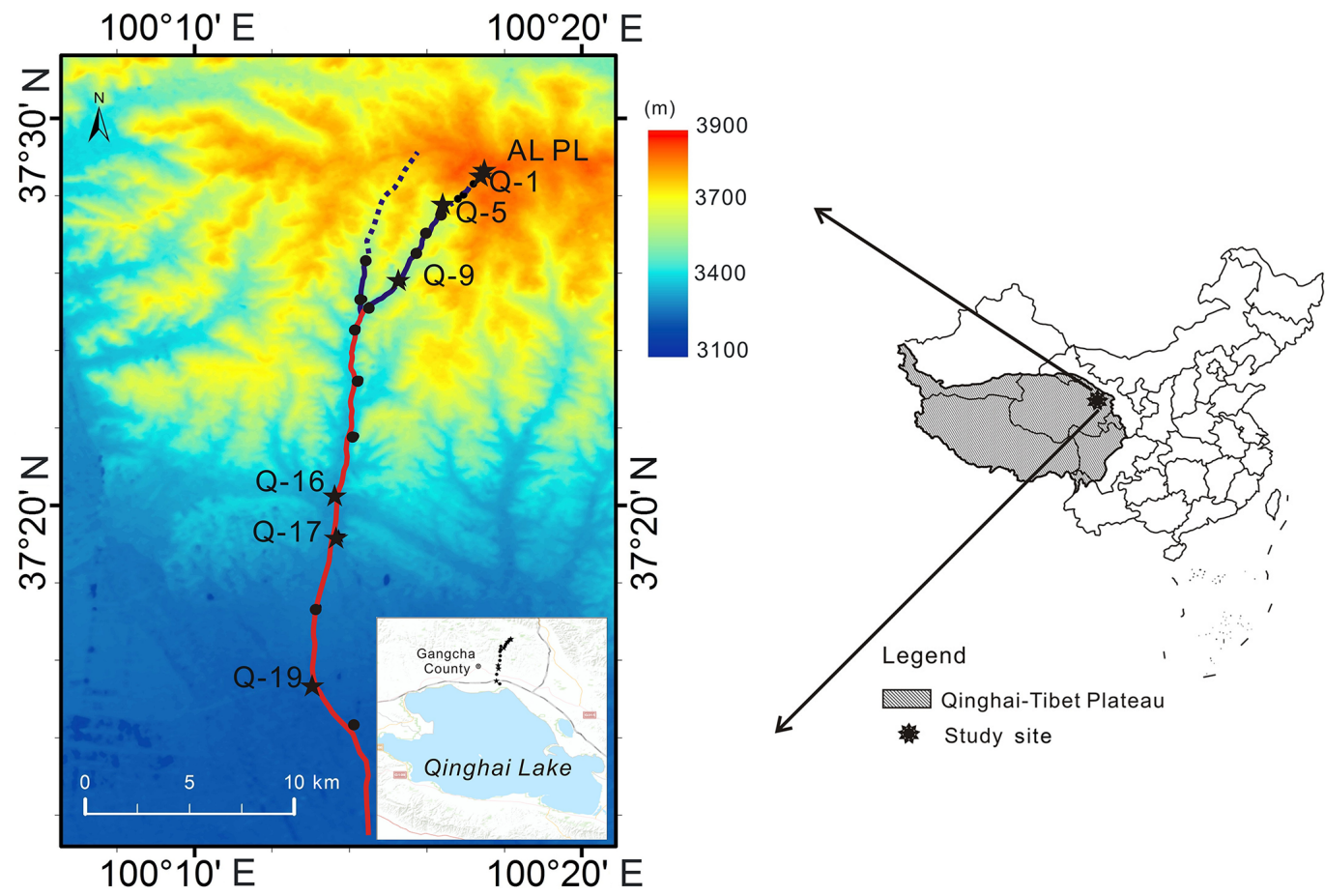

Figure 1. Location of the sampling sites Q-1 to Q-20. Sites marked by a star were selected for FT-ICR MS or ${ }^{14} \mathrm{C}$ age analyses. The AL and PL denote the sampling locations of the active and permafrost layers. The blue line and the red line represent the first-order and second-order stream, respectively, and the blue dashed line denotes the stream without GPS data.

on ice and in the dark. They were transported to a temporary laboratory in Gangcha County within $6 \mathrm{~h}$. Besides soil leachates, water samples $(20 \mathrm{~L}$ each) were collected from 20 sites along the stream (Fig. 1). Sampling sites Q-1 to Q-10 are located in a first-order stream (ca. $8.5 \mathrm{~km}$ long) that originates in the largest thermo-erosion gully, whereas sites Q11 and Q-12 are located in another first-order stream nearby (ca. $6.9 \mathrm{~km}$ long). These two streams merge together to form the main stream, along which sampling sites Q-13 to Q-20 were located. Surface water samples were collected using pre-cleaned HDPE carboys and kept on ice and in the dark until filtering through Whatman $\mathrm{GF} / \mathrm{F}$ filters $(0.7 \mu \mathrm{m})$ within $6 \mathrm{~h}$ after sampling. To obtain enough carbon for ${ }^{14} \mathrm{C}$ analyses, aliquots of the $0.7 \mu \mathrm{m}$ filtrate were concentrated over a crossflow ultrafiltration system with a $1 \mathrm{kDa}$ cut off (Millipore $^{\circledR}$, Pellicon 2 system). The retentates and the remaining filtrate were all stored at $-20^{\circ} \mathrm{C}$ until further analysis. All glassware and $\mathrm{GF} / \mathrm{F}$ filters were combusted at $450^{\circ} \mathrm{C}$ for at least $4 \mathrm{~h}$ prior to use.

\subsection{Hydrological condition, DOC concentration and optical absorbance in alpine streams}

On 1 August 2015, stream water temperature, $\mathrm{pH}$ and conductivity were measured with a portable Horiba W-23XD Water Quality Monitoring System. A portable propeller-type current meter was used to measure the flow rate at the stream cross-section; 5-9 measurements were performed. The water flux was calculated according to the average flow rate and cross-sectional area of the stream. The DOC concentration of each water sample was determined by 3-5 injections on a Shimadzu TOC- $\mathrm{V}_{\mathrm{CPH}}$ analyzer using high temperature combustion, and the coefficient of variance across measurements was $<2 \%$.

The optical properties of the water samples were determined using a Shimadzu UV-1800 spectrophotometer. The scan range was between 200 and $800 \mathrm{~nm}$, and Milli-Q water $\left(18.2 \mathrm{M} \Omega \mathrm{cm}^{-1}\right)$ was used as the blank. A quartz cell with $1.0 \mathrm{~cm}$ pathlength was used. The spectral slope of the $275-295 \mathrm{~nm}$ region $\left(S_{275-295}\right)$, an indicator for the molecular weight of DOM (Helms et al., 2008), was determined by applying log-linear fits across the wavelengths $275-295 \mathrm{~nm}$. Specific UV absorbance ( $\mathrm{SUVA}_{254}$ ), an indicator for relative aromatic $\mathrm{C}$ content, was calculated by dividing the decadic UV absorbance at $254 \mathrm{~nm}$ by DOC concentration (Weishaar et al., 2003).

\subsection{Electrospray ionization Fourier transform ion cyclotron resonance mass spectrometry (ESI FT-ICR MS)}

Selected water samples collected in 2016 from headstream (Q-1), midstream (Q-9), and downstream (Q-17), as well as leachate samples collected from the $\mathrm{AL}$ and $\mathrm{PL}$, were 
prepared for FT-ICR MS analyses. They were subject to solid-phase extraction (SPE) using Bond Elut PPL (Agilent Technologies, $100 \mathrm{mg}$ PPL in $3 \mathrm{~mL}$ cartridge), following the procedures of Dittmar et al. (2008). In order to avoid overloading of the SPE column, the aliquot volume of SPE DOM was calculated based on an average SPE recovery (60\% for permafrost DOM; Ward and Cory, 2015) and a final eluate concentration of $40 \mu \mathrm{g} \mathrm{mL}^{-1}$ (in $2 \mathrm{~mL}$ methanol). The methanol extracts were analyzed on a 9.4 tesla custom-built FT-ICR MS at the National High Magnetic Field Laboratory (NHMFL; Tallahassee, FL, USA; Kaiser et al., 2011). The direct infusion flow rate was $0.7 \mu \mathrm{L} \mathrm{min}{ }^{-1}$. A total of 100 broadband scans between $m / z 150$ and 2000 were co-added for each mass spectrum. After internal calibration in MIDAS Predator Analysis (NHMFL), formulas were assigned based on published rules to signals $>6 \sigma$ root mean square baseline noise (Stubbins et al., 2010) using EnviroOrg ${ }^{{ }^{\mathrm{TM}}}$ software (Corilo, 2015) and categorized by compound class based on the elemental composition of molecular formulas (Kujawinski, 2002; Stenson et al., 2003; Spencer et al., 2014). Formulas with mass measurement accuracy $<0.4 \mathrm{ppm}$ were assigned within the following compositional constraints: $\mathrm{C}_{1-100}, \mathrm{H}_{2-200}, \mathrm{O}_{1-30}, \mathrm{~N}_{0-3}$ and $\mathrm{S}_{0-2}$. A modified aromaticity index $\left(\mathrm{AI}_{\bmod }\right)$ was calculated according to the definition of Koch and Dittmar (2006): $\mathrm{AI}_{\text {mod }}=$ $\frac{1+\mathrm{C}-0.5 \mathrm{O}-\mathrm{S}-0.5(\mathrm{H}+\mathrm{N}+\mathrm{P})}{\mathrm{C}-0.5 \mathrm{O}-\mathrm{S}-\mathrm{N}}$, and if $\mathrm{AI}_{\text {mod }}$ is negative, then $\mathrm{AI}=0$. The groups referenced in this study are (1) aliphatics (Ali.): $\mathrm{H} / \mathrm{C} 1.5-2.0, \mathrm{O} / \mathrm{C}<0.9, \mathrm{~N}=0$; (2) peptide-like (Pep.): $\mathrm{H} / \mathrm{C} 1.5-2.0, \mathrm{O} / \mathrm{C}<0.9, \mathrm{~N}>0$; (3) highly unsaturated compounds (Uns.): $\mathrm{AI}_{\text {mod }}<0.5, \mathrm{H} / \mathrm{C}<1.5$; (4) polyphenols (Pol.): $0.5<\mathrm{AI}_{\mathrm{mod}}<0.67$; and (5) condensed aromatics $(\mathrm{CA}): \mathrm{AI}_{\mathrm{mod}} \geq 0.67$. Some compound groups are ambiguous as the formulae may also occur in alternative isomeric arrangements. The relative abundance of the defined compound class, mean molecular weight and $\mathrm{AI}_{\text {mod }}$ of each sample were all weighted by the relative abundance of signals in each spectrum.

\subsection{Radiocarbon analyses}

Freeze-dried retentates from $1 \mathrm{kDa}$ cutoff ultrafiltration are described as high molecular weight ultrafiltrated dissolved organic matter (HMW UDOM; e.g., Broek et al., 2017). They were fumigated with concentrated hydrochloric acid (12 M) in order to remove inorganic carbon. After that, the samples were analyzed on the Keck Carbon Cycle Accelerator Mass Spectrometry (AMS) facility at the University of California, Irvine, USA. Processing blank and sample preparation backgrounds were subtracted. Radiocarbon concentrations are given as conventional ${ }^{14} \mathrm{C}$ age following Stuiver and Reimer (1993).

\section{Results}

\subsection{Hydrology and DOC concentration from headstream to downstream water}

Discharge increased along the stream reach, from $0.15 \mathrm{~m}^{3} \mathrm{~min}^{-1}$ at the headstream (Q-1) on 1 August 2015 to $24.14 \mathrm{~m}^{3} \mathrm{~min}^{-1}$ (Q-19) (Fig. 2). $\mathrm{pH}$ increased from 7.4 at Q-1 to 8.2 at Q-4 and remained elevated in the middle and lower stream (7.9 to 8.4). Conductivity was relatively constant from Q-1 to Q-6 (35 to $38 \mu \mathrm{sm}^{-1}$ ), then increased at Q-7 and remained elevated downstream (48 to $60 \mu \mathrm{s} \mathrm{cm}^{-1}$ ). The DOC concentration was high in headstream waters (e.g., $12.48 \pm 1.39 \mathrm{mg} \mathrm{L}^{-1}$ at Q-1 and $10.22 \pm 1.09 \mathrm{mg} \mathrm{L}^{-1}$ at $\mathrm{Q}-2$; mean $\pm \mathrm{AD}$, same hereafter) and decreased downstream $\left(3.13 \pm 0.59\right.$ to $5.14 \pm 0.20 \mathrm{mg} \mathrm{L}^{-1}$ from Q-5 to Q-20). The mean DOC concentration of the AL leachates $\left(11.57 \pm 0.77 \mathrm{mg} \mathrm{L}^{-1}\right)$ was an order of magnitude lower than that of the PL leachates $\left(126.40 \pm 14.80 \mathrm{mg} \mathrm{L}^{-1}\right)$.

\subsection{Optical properties of DOM in leachates and stream waters}

Paired $t$ test based on $S_{275-295}$ and $\mathrm{SUVA}_{254}$ of water samples showed no significant interannual variation between the years 2015 and 2016 ( $p=0.716$ and $p=0.321$, respectively). The mean $S_{275-295}$ of 2015 and 2016 samples was $(14.49 \pm 0.34) \times 10^{-3} \mathrm{~nm}^{-1}$ for the AL leachates and $(18.05 \pm 0.94) \times 10^{-3} \mathrm{~nm}^{-1}$ for the PL leachates. In the stream waters, the $S_{275-295}$ ranged from $16.05 \times 10^{-3}$ to $21.80 \times 10^{-3} \mathrm{~nm}^{-1}$, increasing in downstream reaches. The mean $\mathrm{SUVA}_{254}$ was $3.53 \pm 0.17 \mathrm{~L} \mathrm{mg} \mathrm{C}^{-1} \mathrm{~m}^{-1}$ for the AL leachates and $0.95 \pm 0.10 \mathrm{~L} \mathrm{mg} \mathrm{C}^{-1} \mathrm{~m}^{-1}$ for the PL leachates, and decreased in the stream from Q-1 to Q-11 (2.92 to $1.66 \mathrm{~L} \mathrm{mg} \mathrm{C}^{-1} \mathrm{~m}^{-1}$ ), and then remained low (Fig. 3). A strong negative correlation was found between $\mathrm{SUVA}_{254}$ and $S_{275-295}$ for water samples from both years $\left(R^{2}=0.77\right.$, $P<0.01)$.

\subsection{Spatiotemporal change of ${ }^{14} \mathrm{C}$ age of HMW UDOM through fluvial networks}

The ${ }^{14} \mathrm{C}$ age of HMW UDOM of the PL leachate was $4145 \mathrm{yr} \mathrm{BP}$, which was much older than that of the AL leachate (535 yr BP; Fig. 4a). The ${ }^{14} \mathrm{C}$ age of HMW UDOM decreased along the stream from $745 \mathrm{yr} B P$ for the headstream water (Q-1) to $160 \mathrm{yr}$ BP at Q-19, a site close to Qinghai Lake. Besides apparent spatial variability, the ${ }^{14} \mathrm{C}$ age of HMW UDOM also changed temporally. In 2015, the ${ }^{14} \mathrm{C}$ age of HMW UDOM of the headstream water (Q-1) increased from $745 \mathrm{yr}$ BP on 1 August to $1015 \mathrm{yr} \mathrm{BP}$ on 11 August and $1560 \mathrm{yr}$ BP on 5 September (Fig. 4b). 

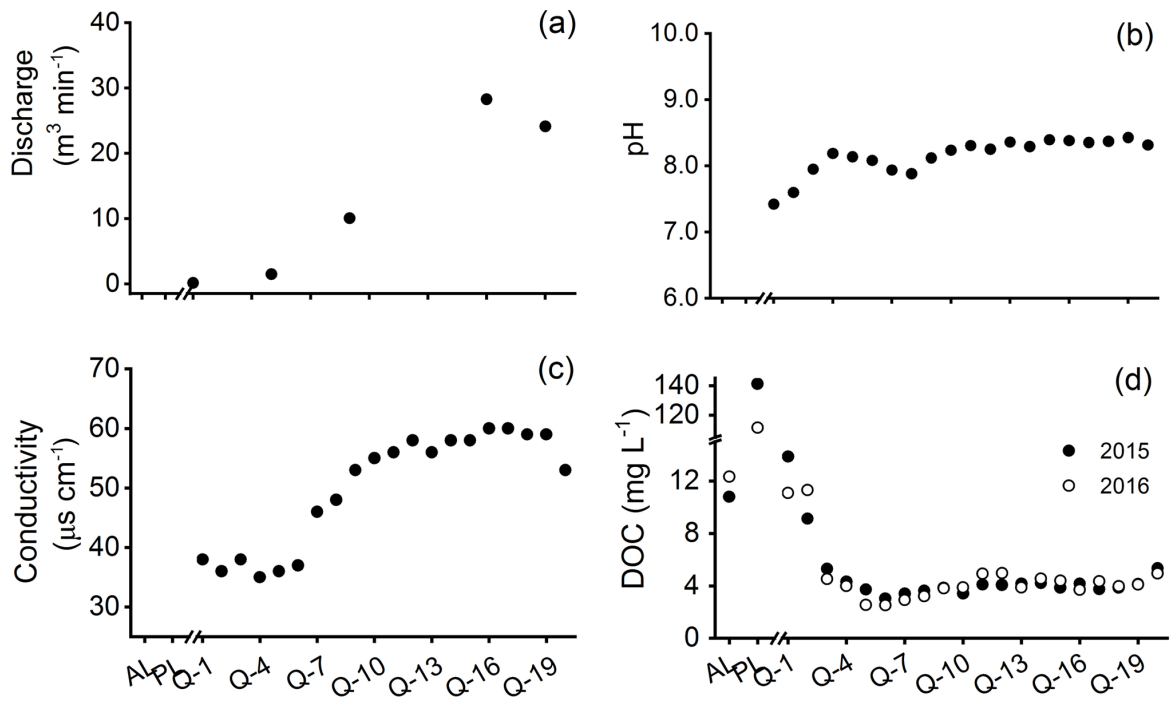

Figure 2. (a) Stream water discharge, (b) $\mathrm{pH}$ and (c) conductivity at the sampling sites in 2015; and (d) DOC concentration in stream water and PL and AL leachates collected in 2015 (filled circles) and 2016 (open circles).
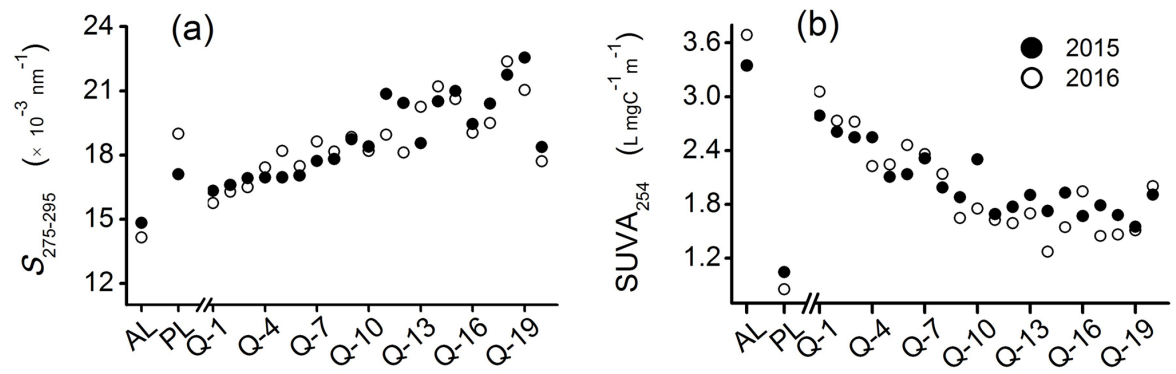

Figure 3. UV-visible optical indices of the stream water and PL and AL leachate samples collected in 2015 (filled circles) and 2016 (open circles) on the QTP: $S_{275-295}$ (a) and SUVA $_{254}(\mathbf{b})$.

\subsection{FT-ICR MS characterization of SPE-DOM}

Compared with the PL leachate, the AL leachate was characterized by higher molecular chemodiversity (14709 vs. 9645 assigned formulae), higher mean molecular weight (498.81 vs. $452.73 \mathrm{Da}$ ) and higher $\mathrm{AI}_{\text {mod }}$ (0.47 vs. 0.30) (Table 1). Molecular-level composition revealed that compounds containing both $\mathrm{N}$ and $\mathrm{S}$ were only detected in the AL leachates and headstream waters. The AL leachate contained $54.28 \%$ highly unsaturated compounds, $27.10 \%$ polyphenols and $17.23 \%$ condensed aromatic compounds, whereas the proportion of aliphatics and peptide-like compounds was minor (ca. $1.30 \%$ ). Compared with the AL leachate, the PL leachate comprised a higher proportion of highly unsaturated compounds $(74.23 \%)$ and aliphatics and peptide-like compounds (10.04\%), but a lower proportion of polyphenols $(11.33 \%)$ and condensed aromatics $(4.32 \%)$.

Along the stream (Q-1, Q-9 and Q-17), the molecular chemodiversity, mean molecular weight and modified aro- maticity index of SPE-DOM decreased from 14924 to 11074 , 510.1 to $486.5 \mathrm{Da}$ and 0.43 to 0.36 , respectively (Table 1 ). The relative abundance of aromatics (condensed aromatics and polyphenols) decreased by $48 \%$ (35.7\% at Q-1 vs. $18.4 \%$ at Q-17), whereas that of highly unsaturated compounds increased by $28 \%$ (62.8\% at Q-1 vs. $80.3 \%$ at Q-17). Aliphatics and peptide-like compounds were minor components of stream DOM $(<1.3 \%)$ and did not exhibit a downstream trend (Table 1; Fig. 5).

\section{Discussion}

\subsection{AL leachates as a major source of stream DOM}

The UV-visible optical parameters and molecular formulas resolved by FT-ICR MS show that the AL and PL leachates have different chemical compositions (Tables 1 and 2; Fig. 5). This difference is likely attributed to the selective release of aromatic components from AL and carbohy- 

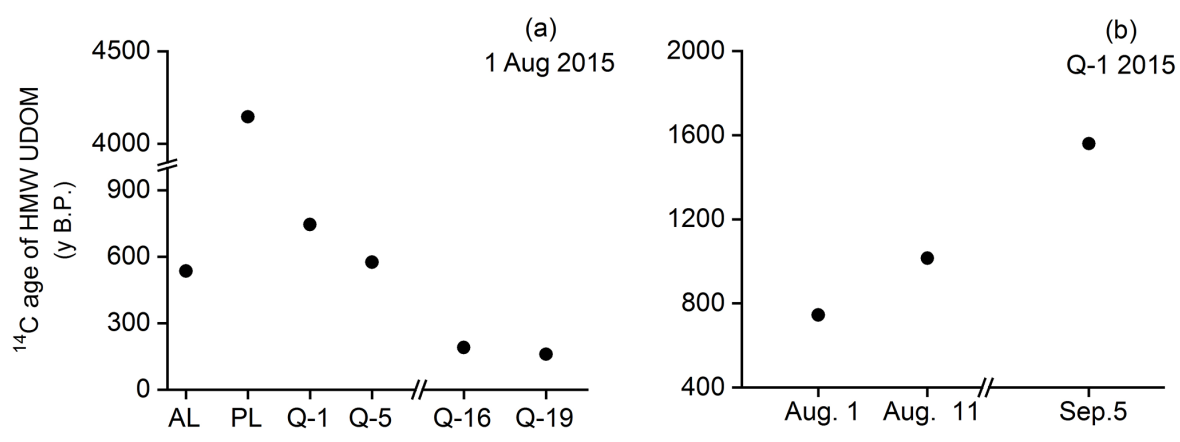

Figure 4. Variations of ${ }^{14} \mathrm{C}$ age of HMW UDOM across the alpine stream spatially (a), and at headstream Q-1 temporally (b).

Table 1. The number of molecular formulas assigned, modified aromaticity index ( $\left.\mathrm{AI}_{\text {mod }}\right)$, mean molecular weight (mean $\left.\mathrm{MW}\right)$ and relative abundance of defined compound classes detected by FT-ICR MS for DOM samples from the QTP, including soil leachates (AL and PL) and stream waters (Q-1, Q-9 and Q-17). CA denotes condensed aromatics, Pol. denotes polyphenols, Uns. denotes highly unsaturated compounds, Ali. denotes aliphatic and Pep. denotes peptides. The molecule signatures of AL and PL leachate DOM can also be found in Wang et al. (2018).

\begin{tabular}{lrrrrrrrr}
\hline Sample & $\begin{array}{r}\text { Formulas } \\
\text { assigned }\end{array}$ & $\begin{array}{r}\text { Mean } \\
\text { MW }\end{array}$ & $\mathrm{AI}_{\text {mod }}$ & $\begin{array}{r}\text { CA } \\
(\%)\end{array}$ & $\begin{array}{r}\text { Pol. } \\
(\%)\end{array}$ & $\begin{array}{r}\text { Uns. } \\
(\%)\end{array}$ & $\begin{array}{r}\text { Ali. } \\
(\%)\end{array}$ & $\begin{array}{r}\text { Pep. } \\
(\%)\end{array}$ \\
\hline AL & 14709 & 498.81 & 0.47 & 17.23 & 27.10 & 54.28 & 1.16 & 0.14 \\
PL & 9645 & 452.73 & 0.30 & 4.32 & 11.33 & 74.23 & 7.92 & 2.12 \\
Q-1 & 14924 & 510.07 & 0.43 & 12.05 & 23.69 & 62.85 & 1.14 & 0.14 \\
Q-9 & 11724 & 500.19 & 0.38 & 6.86 & 15.82 & 76.32 & 0.86 & 0.06 \\
Q-17 & 11074 & 486.50 & 0.36 & 5.53 & 12.91 & 80.31 & 1.11 & 0.08 \\
\hline
\end{tabular}

drate/protein components from the deep PL during the soil thawing process, which was observed in our previous study (Wang et al., 2018). Since chemical composition impacts the reactivity of DOM (Kellerman et al., 2015), the differing chemical composition between the AL and PL leachates that enter the stream may influence bioavailability (Vonk et al., 2013) and photolability (Stubbins et al., 2017). Thus, distinguishing the DOM source is crucial for understanding in-stream biogeochemical processes in permafrost-impacted systems. DOM may originate from a variety of sources including permafrost soil (AL and PL) leaching, in situ microbial production and wet deposition from snow and rain. At the headstream site (Q-1), however, the dominant source of DOM is permafrost soil leaching, as short residence times at the gully head restrict in-stream production, and wet deposition is likely negligible due to low DOC concentrations in Tibetan glaciers $\left(0.2-3.3 \mu \mathrm{g} \mathrm{mL}^{-1}\right.$; Spencer et al., 2014). Assuming that headstream DOM is derived only from permafrost soil leaching, we are able to estimate the relative contributions of DOM from the AL and PL.

The mean DOC concentration of the AL leachate based on samples from 2015 and $2016\left(11.57 \pm 0.77 \mathrm{mg} \mathrm{L}^{-1}\right)$ is similar to that of the headstream (Q-1; ca. $12.48 \pm$ $1.39 \mathrm{mg} \mathrm{L}^{-1}$ ), but substantially lower than that of the PL leachates $\left(126.40 \pm 14.80 \mathrm{mg} \mathrm{L}^{-1}\right)$, supporting a predominance of $\mathrm{AL}$ leachate DOM in stream waters. In addi- tion, the $\mathrm{SUVA}_{254}$ is $3.52 \pm 0.17 \mathrm{Lmg} \mathrm{C}^{-1} \mathrm{~m}^{-1}$ for $\mathrm{AL}$ leachates and $0.95 \pm 0.10 \mathrm{~L} \mathrm{mg} \mathrm{C}^{-1} \mathrm{~m}^{-1}$ for PL leachates, whereas the $S_{275-295}$ is $(14.49 \pm 0.34) \times 10^{-3} \mathrm{~nm}^{-1}$ for AL leachates and $(18.05 \pm 0.94) \times 10^{-3} \mathrm{~nm}^{-1}$ for PL leachates. Similar optical properties and DOC concentrations between $\mathrm{AL}$ leachates and the headstream water $(3.52 \pm$ $0.17 \mathrm{Lmg} \mathrm{C}^{-1} \mathrm{~m}^{-1}$ vs. $2.92 \pm 0.13 \mathrm{Lmg} \mathrm{C}^{-1} \mathrm{~m}^{-1}$ for SUVA $_{254}$ and $(14.49 \pm 0.34) \times 10^{-3} \mathrm{~nm}^{-1}$ vs. $\quad(16.05 \pm$ $0.28) \times 10^{-3} \mathrm{~nm}^{-1}$ for $\left.S_{275-295}\right)$ support the finding that AL leachate dominates stream DOM. Furthermore, the stream water at Q-1 has a ${ }^{14} \mathrm{C}$ age of HMW UDOM of $745 \mathrm{yr} \mathrm{BP}$, close to that of the $\mathrm{AL}$ leachate $(535 \mathrm{yr} \mathrm{BP})$, and much younger than that of the PL leachate (4145 yr BP). Broek et al. (2017) found that although the ${ }^{14} \mathrm{C}$ age of HMW UDOM was significantly younger than that of bulk DOM from the north central Pacific Ocean, the offset between them is constant in the whole marine system. This result suggests that HMW UDOM can serve as a proxy for bulk DOM. Here we estimate the portion of AL- and PL-derived organic carbon by using a binary mixing model based on $\Delta^{14} \mathrm{C}$ values of HMW UDOM (Criss, 1999; $\Delta^{14} \mathrm{C}$ values can be found in 

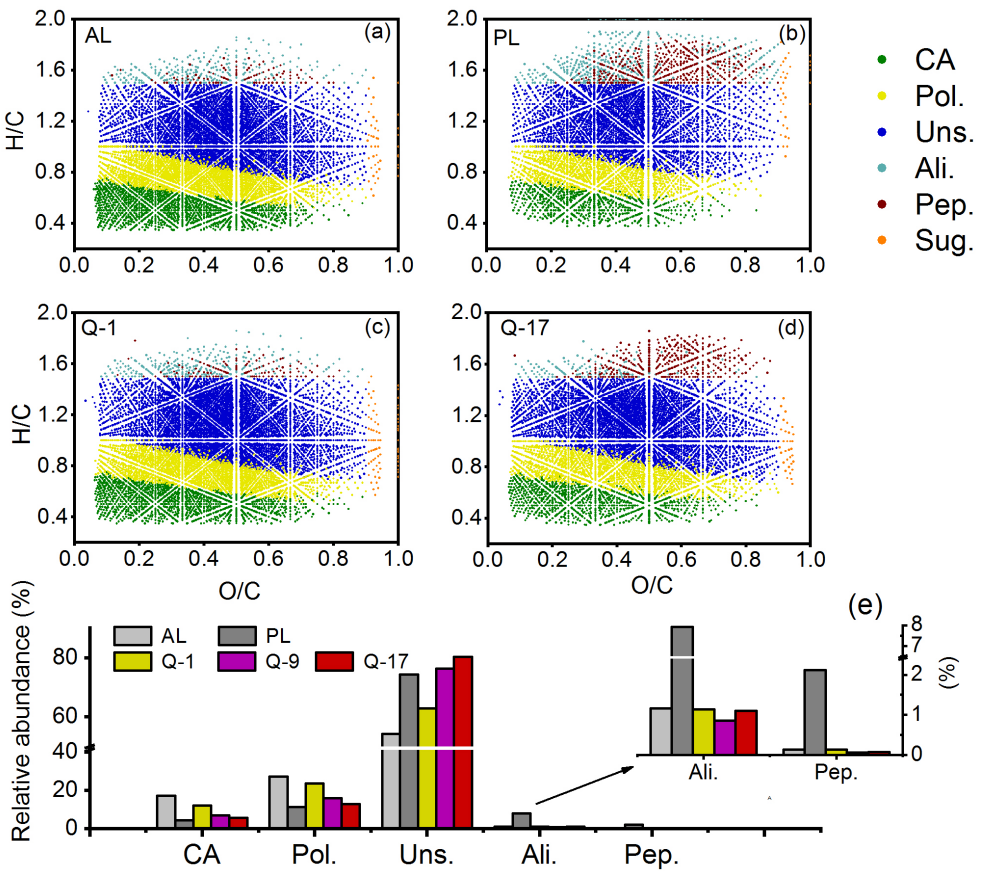

Figure 5. van Krevelen diagrams of AL leachate DOM (a), PL leachate DOM (b), headstream DOM Q-1 (c), downstream DOM Q-17 (d) and the relative abundance of defined compound class in different samples (e). CA denotes condensed aromatics, Pol. denotes polyphenols, Uns. denotes highly unsaturated compounds, Ali. denotes aliphatics, Pep. denotes peptides; and Sug. denotes sugar. The van Krevelen plots of AL and PL leachate DOM were modified from Wang et al. (2018).
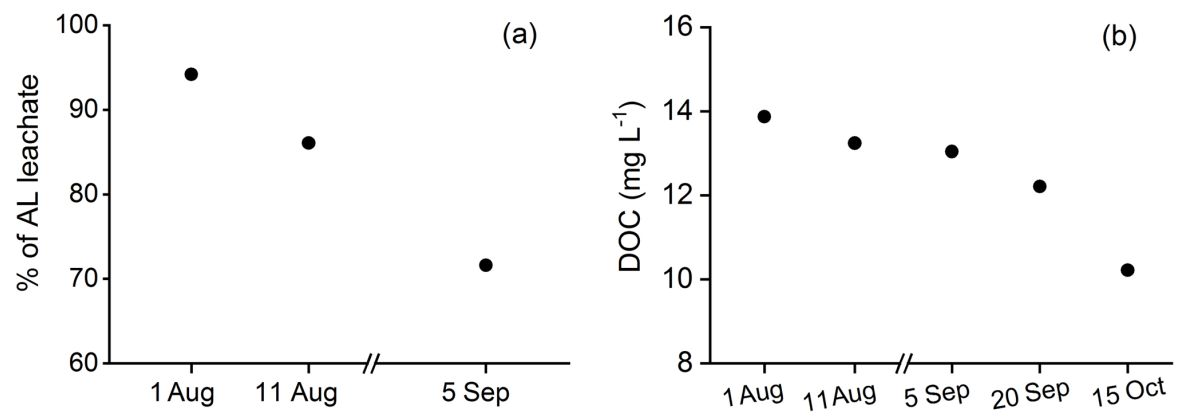

Figure 6. (a) Relative contribution of AL leachate DOM to headstream DOM (Q-1); and (b) temporal variation of the DOC concentration at headstream Q-1.

the Supplement Table S1):

$\Delta{ }^{14} \mathrm{C}_{\mathrm{DOM}}=f_{\mathrm{AL}} \times \Delta^{14} \mathrm{C}_{\mathrm{AL}}+f_{\mathrm{PL}} \times \Delta^{14} \mathrm{C}_{\mathrm{PL}}$

$1.0=f_{\mathrm{AL}}+f_{\mathrm{PL}}$.

According to this model, ca. $94 \%$ of DOC collected from stream site Q-1 on 1 August 2015 originated from the AL (Fig. 6a). Headstream ${ }^{14} \mathrm{C}$ age of HMW UDOM increased from summer to fall (Fig. 4b), reflecting an enhanced contribution of old carbon from the deeper soils (i.e., PL); however, the AL still accounted for $\geq 72 \%$ of total DOC exported (Fig. 6a). This binary mixing model may overestimate the contribution of AL to stream DOC since PL-derived DOC may be degraded faster than AL-derived DOC, due to the high biolability of ancient permafrost carbon as shown in Arctic ecosystems (Vonk et al., 2013). Nonetheless, the AL appears as a major contributor to stream DOC in the QTP.

Seasonal variation of the ${ }^{14} \mathrm{C}$ age (Fig. $4 \mathrm{~b}$ ) has been previously observed in DOM from high-latitude permafrost areas in Alaska (Aiken et al., 2014; O'Donnell et al., 2014), with the most enriched ${ }^{14} \mathrm{C}$ values observed in the spring and becoming more depleted through summer-fall and/or during winter. Our result also shows seasonal variations in the ${ }^{14} \mathrm{C}$ age and optical parameters of headstream DOM. From sum- 
mer to fall, the $\mathrm{SUVA}_{254}$ of stream DOM at Q-1 decreased from 2.79 to $2.36 \mathrm{mg} \mathrm{C}^{-1} \mathrm{~m}^{-1}$, whereas the $S_{275-295}$ increased from $16.33 \times 10^{-3}$ to $16.96 \times 10^{-3} \mathrm{~nm}^{-1}$. These temporal changes indicated that the proportion of aromatic components and high molecular weight compounds decreased with the deepening of the PL. The mean monthly air temperature of Gangcha County, after reaching the maximum in July (ca. $10.5^{\circ} \mathrm{C}$ ), decreases to $2.1^{\circ} \mathrm{C}$ in September (data from http://data.cma.cn, last access: 10 August 2017). As air temperature drops, surface soils freeze earlier than deeper soils, leading to an increase in the relative contribution of deep soil carbon (i.e., PL) to stream DOM, although the DOC concentration in Q-1 decreased from 13.87 to $10.22 \mathrm{mg} \mathrm{L}^{-1}$ (Fig. 6b).

\subsection{Selective removal of DOM along the alpine stream on the QTP}

The DOC concentration decreased (12.48 to $3.13 \mathrm{mg} \mathrm{L}^{-1}$ ) from the upper to the midstream (Q-1 to Q-5), which may be attributed to several reasons such as aggregation or precipitation, a dilution effect and in-stream degradation of DOM. Aggregation or precipitation is likely unimportant in our case because the steep gradient of sampling sites prevents significant sediment and floc deposition on stream bedrock, although this effect cannot be excluded completely. Dilution from groundwater is likely since groundwater discharge sustains baseflow of rivers and streams in the QTP $(\mathrm{Ge}$ et al., 2008). Downstream groundwater inputs were further supported by the order of magnitude increase in discharge (1.49 to $24.14 \mathrm{~m}^{3} \mathrm{~min}^{-1}$ ) and increase in conductivity (37 to $60 \mathrm{\mu s} \mathrm{cm}^{-1}$ ). Moreover, downstream DOC concentrations remained about $3.0-4.0 \mathrm{mg} \mathrm{L}^{-1}$ (Q-15 to Q-20), indicative of the low DOC concentrations of groundwater. Conversely, a tributary that originated from another thermo-erosion gully merged into the study stream; however, the different tributaries exhibited similar DOC concentrations (e.g., Q-9 and Q-10 vs. Q-11 and Q-12; Fig. 2d). The similarities in DOC concentrations were attributed to homogeneity in dominant vegetation, soil type and climate, and thus, homogeneity in DOM inputs to the different tributaries in our study area. Therefore, additional tributaries could not explain the spatial pattern of DOC concentration.

Despite evident dilution, DOC attenuation could be partly due to in-stream degradation given several lines of evidence from optical properties, radiocarbon age and molecular composition. The UV-visible optical parameters, $S_{275-295}$ and $\mathrm{SUVA}_{254}$, have been widely used to assess molecular weight and aromaticity of DOM, respectively (Weishaar et al., 2003; Helms et al., 2008; Spencer et al., 2009; Mann et al., 2012). A downstream increase for $S_{275-295}$ regardless of sampling time (Fig. 3a) reflects selected degradation of high molecular weight compounds, leading to the enrichment of low molecular weight DOM. In addition to $S_{275-295}, \mathrm{SUVA}_{254}$ varied from 1.50 to $2.92 \mathrm{~L} \mathrm{mg} \mathrm{C}^{-1} \mathrm{~m}^{-1}$, showing a general decrease downstream (Fig. 3b). Lignin, an aromatic biopolymer specific for vascular plants (Hedges et al., 1997), is relatively resistant to biodegradation (Hedges et al., 1985), but highly photolabile (Lanzalunga and Bietti, 2000). Cory et al. (2014) found that sunlight accounts for $70 \%$ to $95 \%$ of water column carbon processing in Arctic rivers and lakes. Given strong solar radiation and long sunshine duration $(\sim 3000 \mathrm{~h}$ per year) on the QTP (Peng et al., 2015), photodegradation could be an important pathway for carbon removal in QTP streams. A strong negative correlation between $S_{275-295}$ and SUVA $_{254}\left(R^{2}=0.73, p<0.01\right)$ indicates that photodegradation of high molecular weight aromatic compounds (like lignin) may play a role in the decrease of mean molecular weight of DOM along the stream, despite the fact that microbial degradation might also contribute to the molecular modification in-stream.

Similar to $\mathrm{SUVA}_{254}$ and $S_{275-295}$, the data from FT-ICR MS also show a downstream decrease in aromaticity $\left(\mathrm{AI}_{\text {mod }}\right.$ : 0.43 to 0.36 ) and mean molecular weight of stream DOM (510.0 to $486.5 \mathrm{Da}$; Table 1). Compared with headstream DOM at Q-1, DOM at Q-9 and Q-17 was characterized by a lower proportion of condensed aromatics and polyphenols and enriched in highly unsaturated compounds (Table 1). The decrease in relative abundance of aromatic compounds is consistent with the reports for the photolability of aromatic formulas within permafrost, river and ocean DOM (Stubbins and Dittmar, 2015; Stubbins et al., 2017).

As discussed in Sect. 4.1, AL is the principal contributor to stream DOM. Thus, tracing AL-derived DOM is paramount in estimating biogeochemical processes of carbon in the stream. FT-ICR MS identified 6409 molecular formulas specific to AL leachates (i.e., not observed in the PL; Table 2). Through various stream processes, some AL-specific formulas were removed from the DOM pool (from $17 \%$ by Q-1 up to $59 \%$ by Q-17), which accounted for $66 \%$ of the aromatic compounds and $51 \%$ of the highly unsaturated compounds (Table 2). Molecular formulas containing $\mathrm{N}$ and/or $\mathrm{S}$ were more labile in the fluvial networks than $\mathrm{CHO}$ formulas, with $84 \%$ of S-containing formulas and $100 \%$ of S- and $\mathrm{N}$-containing formulas lost (Table 2). Furthermore, the removal of DOM formulas (ca. $83 \%$ of AL-specific formulas, and $>95 \%$ of AL-specific formulas) occurred in the upper stream and midstream (leachates to Q-9). Concurrent with the rapid loss of AL-specific formulas, some new molecular formulas were detected by FT-ICR MS, which was mainly attributed to in situ production by stream algae/microbes, an import from groundwater and molecular transformation of leachate DOM. The van Krevelen diagram showed that the new products were mainly composed of highly unsaturated molecules (Fig. S1 in the Supplement). The addition of new molecular formulas was also reflected by the ${ }^{14} \mathrm{C}$ enrichment in the middle and lower stream (Fig. 3b).

Overall, our multiple analyses demonstrate a rapid and selective degradation of stream DOM on the QTP. The attenuation of aromatic compounds and enrichment of highly un- 


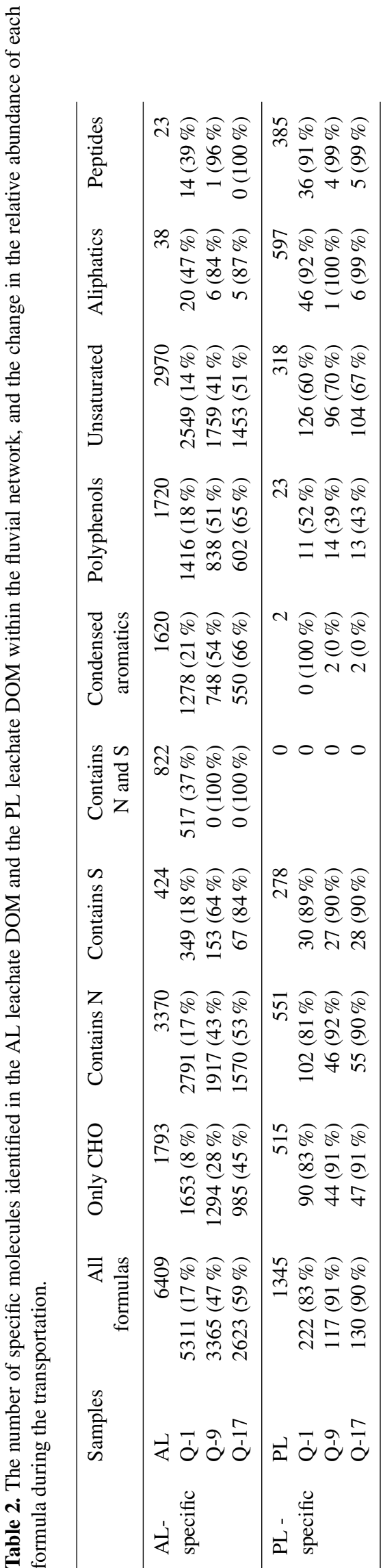

saturated compounds could change the environmental photoand biolability of DOM, increasing the relative importance of photodegradation in the upper stream and biodegradation in the lower stream. The continuous change in chemical properties of DOM along the alpine stream flow path has the potential to shift the aquatic microbial community since DOM serves as an important energy and nutrient source (Wild et al., 2014).

\subsection{Prediction of in-stream carbon dynamic under continued warming}

The DOC concentrations, UV-visible optical parameters and FT-ICR MS data all suggest that currently, the PL is a minor source to stream DOM (see Sect. 4.1). However, the QTP is a sensitive area to climate change, with a rate of air temperature rise that is approximately 3 times the global rate (Qiu, 2008). According to climate model predictions, spatial average temperatures of the QTP will increase by 0.68 $0.98^{\circ} \mathrm{C}$ for the period of 2015-2050 (Zhu et al., 2013), and in 2050, the mean AL thickness on the QTP permafrost will increase by approximately $0.3-0.8 \mathrm{~m}$ more than that in 2010 (Zhang and $\mathrm{Wu}, 2012$ ). With the deepening of the $\mathrm{AL}$, carbon that is currently stable in the PL will be thawed and mobilized into downslope aquatic environments, which inevitably changes the relative proportion of AL vs. PL contributions to stream DOM. Thus, it is important to trace the chemical change of PL leachates along the stream. The PL leachate contained only 1345 formulas unique to the PL leachate in comparison to the $\mathrm{AL}$, accounting for $14 \%$ of total assigned formulas (Table 2). Most PL-specific formulas were more biolabile components, e.g., aliphatics and peptide-like assignments $(73 \%)$, followed by highly unsaturated formulas $(23.6 \%)$ and aromatics $(1.9 \%)$. At the downstream site (i.e., Q-17), $90 \%$ of these PL-specific molecular formulas were lost, substantially higher than that of AL-specific formulas (59\%). Furthermore, the vast majority of PL-specific formulas were lost within $<1 \mathrm{~km}(\mathrm{Q}-1: 83 \%)$, whereas only $17 \%$ of AL-specific formulas were lost by Q-1 (Table 2). Therefore, the FT-ICR MS data demonstrate that permafrost thaw can trigger a rapid degradation of old organic carbon that was previously frozen in soils for thousands of years (Fig. 3a). This is consistent with findings in Arctic fluvial networks that show that the utilization of ancient permafrost carbon in headstream waters was rapid (Mann et al., 2015; Frey et al., 2016). Therefore, we hypothesize that with enhanced leaching of deep soil $\mathrm{C}$ under continued warming on the QTP, DOM in alpine streams will be more enriched in biolabile aliphatics/peptides and depleted in photolabile aromatics

Finally, despite substantial in-stream degradation, some old permafrost-derived carbon (i.e., polyphenols and highly unsaturated compounds) could persist downstream. In addition, $\mathrm{CO}_{2}$ produced by respiration of old DOC could be utilized by stream algae to biosynthesize new DOM with an old carbon age. These effects resulted in a sustained deviation 
from modern ${ }^{14} \mathrm{C}$ age of HMW UDOM in the alpine stream (e.g., $160 \mathrm{yr}$ BP at Q-19), and were even detected in large rivers on the QTP (e.g., Yangtze River and Yellow River; Qu et al., 2017). Thus, under continued warming, a greater quantity of older $\mathrm{C}$ may be transported into large watersheds on the QTP, and thereby exert an important role in biogeochemical cycles there since older carbon has different photo- and biolability from young carbon in AL soils.

\section{Conclusions}

Permafrost thaw represents positive feedbacks to climate change, but its carbon alteration and removal mechanism is not well known, particularly for the alpine permafrost such as the QTP. Here we use multiple analytical methods (e.g., FTICR MS, radiocarbon and UV-visible spectroscopy) to trace spatial and temporal variability of permafrost DOM along an alpine stream in the northeastern QTP, from which four conclusions have been reached.

Presently, the AL is the major source to stream DOM with relatively high aromaticity. This character, combined with strong solar radiation on the QTP, suggests sunlight may be an important driver for DOM removal in alpine fluvial networks, which was corroborated by an almost $60 \%$ loss of AL-specific formulas from the thermo-erosion gully head to downstream waters.

From summer to fall (seasonal permafrost thawingfreezing cycle), the concentrations and chemical composition of stream DOM varied significantly at the thermo-erosion gully head. Even though the total amount of the leached DOC decreased, the contribution of deep permafrost carbon with lower aromaticity and lower MW increased, reflected by an increase of ${ }^{14} \mathrm{C}$ age of HMW UDOM and a decrease in aromaticity of DOM.

Although both the AL and PL leachate DOM underwent rapid degradation in the alpine stream, some components with old ${ }^{14} \mathrm{C}$ age were stable to degradation and could be transported downstream, causing ${ }^{14} \mathrm{C}$ values that were more depleted than modern radiocarbon age downstream in our study, and even in large watersheds as observed in $\mathrm{Qu}$ et al. (2017).

With deepening of the AL under continued climate warming on the QTP, currently stable PL soils will thaw and release greater amounts of old, aliphatics and peptide-like DOM to downstream waters. This change in source and chemical composition will make microbial degradation more important for carbon processing and may shift downstream microbial communities, even in large watershed systems. All these factors should be taken into account when interpreting alpine permafrost carbon dynamics under the amplified warming trend observed on the QTP.
Data availability. The

dataset https://doi.org/10.6084/m9.figshare.7301246.v1 contains the raw data about bulk property of stream waters as well as optical parameters, radiocarbon and FTICR MS of dissolved organic matter in an alpine stream on the Qinghai-Tibet Plateau (Xu, 2018).

Supplement. The supplement related to this article is available online at: https://doi.org/10.5194/bg-15-6637-2018-supplement.

Author contributions. YW, YY and YX designed study and collected samples. YW, YX, DW and WX performed lab experiments. RGMS, DCP, AMK and PZ supplied FT-ICRMS data. HR measured radiocarbon age of DOM. All authors contributed to data interpretation and manuscript preparation.

Competing interests. The authors declare that they have no conflict of interest.

Acknowledgements. This work was financially supported by the National Basic Research Program of China (2014CB954001). Yinghui Wang thanks the China Scholarship Council for supporting study in the United States of America as a joint PhD student. We are grateful to Futing Liu, Yanyan Yan, Shangzhe Zhou and Xinyu Zhang for assistance in the field. Rudolf Jaffé and two anonymous reviewers are thanked for constructive comments. FT-ICR MS was supported by NSF (DMR-1157490).

Edited by: Steven Bouillon

Reviewed by: Rudolf Jaffe and two anonymous referees

\section{References}

Abbott, B. W., Jones, J. B., Godsey, S. E., Larouche, J. R., and Bowden, W. B.: Patterns and persistence of hydrologic carbon and nutrient export from collapsing upland permafrost, Biogeosciences, 12, 3725-3740, https://doi.org/10.5194/bg-12-3725-2015, 2015.

Aiken, G. R., Spencer, R. G. M., Striegl, R. G., Schuster, P. F., and Raymond, P. A.: Influences of glacier melt and permafrost thaw on the age of dissolved organic carbon in the Yukon River basin, Global Biogeochem. Cy., 28, 525-537, 2014.

Bockheim, J. G. and Munroe, J. S.: Organic carbon pools and genesis of alpine soils with permafrost: a review, Arct. Antarct. Alp. Res., 46, 987-1006, 2014.

Broek, T. A. B., Walker, B. D., Guilderson, T. P., and McCarthy, M. D.: Coupled ultrafiltration and solid phase extraction approach for the targeted study of semi-labile high molecular weight and refractory low molecular weight dissolved organic matter, Mar. Chem., 194, 146-157, 2017.

Corilo, Y. E.: EnviroOrg, Florida State University, 2015.

Cory, R. M., Crump, B. C., Dobkowski, J. A., and Kling, G. W.: Surface exposure to sunlight stimulates $\mathrm{CO}_{2}$ release from permafrost soil carbon in the Arctic, P. Natl. Acad. Sci. USA, 110, 3429-3434, 2013. 
Cory, R. M., Ward, C. P., Crump, B. C., and Kling, G. W.: Sunlight controls water column processing of carbon in arctic fresh waters, Science, 345, 925-928, 2014.

Criss, R. E.: Principles of stable isotope distribution, Oxford University Press, New York, 1999.

Dittmar, T., Koch, B., Hertkorn, N., and Kattner, G.: A simple and efficient method for the solid-phase extraction of dissolved organic matter (SPE-DOM) from seawater, Limnol. Oceanogr.Meth., 6, 230-235, 2008.

Drake, T. W., Wickland, K. P., Spencer, R. G., McKnight, D. M., and Striegl, R. G.: Ancient low-molecular-weight organic acids in permafrost fuel rapid carbon dioxide production upon thaw, $\mathrm{P}$. Natl. Acad. Sci. USA, 112, 13946-13951, 2015.

Frey, K. E. and Smith, L. C.: Amplified carbon release from vast West Siberian peatlands by 2100, Geophys. Res. Lett., 32, L09401, https://doi.org/10.1029/2004GL022025, 2005.

Frey, K. E., Sobczak, W. V., Mann, P. J., and Holmes, R. M.: Optical properties and bioavailability of dissolved organic matter along a flow-path continuum from soil pore waters to the Kolyma River mainstem, East Siberia, Biogeosciences, 13, 2279-2290, https://doi.org/10.5194/bg-13-2279-2016, 2016.

Ge, S., Wu, Q. B., Lu, N., Jiang, G. L., and Ball, L.: Groundwater in the Tibet Plateau, western China, Geophys. Res. Lett., 35, 80-86, 2008.

Hedges, J. I., Cowie, G. L., Ertel, J. R., James Barbour, R., and Hatcher, P. G.: Degradation of carbohydrates and lignins in buried woods, Geochim. Cosmochim. Ac., 49, 701-711, 1985.

Hedges, J. I., Keil, R. G., and Benner, R.: What happens to terrestrial organic matter in the ocean?, Org. Geochem., 27, 195-212, 1997.

Helms, J. R., Stubbins, A., Ritchie, J. D., Minor, E. C., Kieber, D. J., and Mopper, K.: Absorption spectral slopes and slope ratios as indicators of molecular weight, source, and photobleaching of chromophoric dissolved organic matter, Limnol. Oceanogr., 53, 955-969, 2008.

Kaiser, N. K., Quinn, J. P., Blakney, G. T., Hendrickson, C. L., and Marshall, A. G.: A novel 9.4 tesla FTICR mass spectrometer with improved sensitivity, mass resolution, and mass range, J. Am. Soc. Mass Spectr., 22, 1343-1351, 2011.

Kang, S., Xu, Y., You, Q., Flügel, W.-A., Pepin, N., and Yao, T.: Review of climate and cryospheric change in the Tibetan Plateau, Environ. Res. Lett., 5, 015101, https://doi.org/10.1088/17489326/1085/1081/015101, 2010.

Kellerman, A. M., Kothawala, D. N., Dittmar, T., and Tranvik, L. J.: Persistence of dissolved organic matter in lakes related to its molecular characteristics, Nat. Geosci., 8, 454-457, 2015.

Kellerman, A. M., Guillemette, F., Podgorski, D. C., Aiken, G. R., Butler, K. D., and Spencer, R. G. M.: Unifying concepts linking dissolved organic matter composition to persistence in aquatic ecosystems, Environ. Sci. Technol., 52, 2538-2548, 2018.

Koch, B. P. and Dittmar, T.: From mass to structure: an aromaticity index for high-resolution mass data of natural organic matter, Rapid Commun. Mass Sp., 20, 926-932, 2006.

Koven, C. D., Ringeval, B., Friedlingstein, P., Ciais, P., Cadule, P., Khvorostyanov, D., Krinner, G., and Tarnocai, C.: Permafrost carbon-climate feedbacks accelerate global warming, P. Natl. Acad. Sci. USA, 108, 14769-14774, 2011.

Kujawinski, E. B.: Electrospray ionization fourier transform ion cyclotron resonance mass spectrometry (ESI FT-ICR MS): Charac- terization of complex environmental mixtures, Environ. Forensics, 3, 207-216, 2002.

Lanzalunga, O. and Bietti, M.: Photo- and radiation chemical induced degradation of lignin model compounds, J. Photochem. Photobiol. B, 56, 85-108, 2000.

Laudon, H., Berggren, M., Ågren, A., Buffam, I., Bishop, K., Grabs, T., Jansson, M., and Köhler, S.: Patterns and dynamics of dissolved organic carbon (DOC) in boreal streams: the role of processes, connectivity, and scaling, Ecosystems, 14, 880-893, 2011.

Mann, P. J., Davydova, A., Zimov, N., Spencer, R. G. M., Davydov, S., Bulygina, E., Zimov, S., and Holmes, R. M.: Controls on the composition and lability of dissolved organic matter in Siberia's Kolyma River basin, J. Geophys. Res.-Biogeo., 117, G011028, https://doi.org/10.1029/2011jg001798, 2012.

Mann, P. J., Eglinton, T. I., McIntyre, C. P., Zimov, N., Davydova, A., Vonk, J. E., Holmes, R. M., and Spencer, R. G. M.: Utilization of ancient permafrost carbon in headwaters of Arctic fluvial networks, Nat. Commun., 6, 7856, https://doi.org/10.1038/ncomms8856, 2015.

Mu, C., Zhang, T., Zhang, X., Li, L., Guo, H., Zhao, Q., Cao, L., Wu, Q., and Cheng, G.: Carbon loss and chemical changes from permafrost collapse in the northern Tibetan Plateau, J. Geophys. Res.-Biogeo., 121, 1781-1791, https://doi.org/10.1002/2015JG003235, 2016.

O’Donnell, J. A., Aiken, G. R., Walvoord, M. A., Raymond, P. A., Butler, K. D., Dornblaser, M. M., and Heckman, K.: Using dissolved organicmatter age and composition to detect permafrost thaw in boreal watersheds of interior Alaska, J. Geophys. Res.Biogeo., 119, 2155-2170, 2014.

Peng, S., Du, Q., Wang, L., Lin, A., and Hu, B.: Long-term variations of ultraviolet radiation in Tibetan Plateau from observation and estimation, Int. J. Climatol., 35, 1245-1253, 2015.

Petrone, K. C., Jones, J. B., Hinzman, L. D., and Boone, R. D.: Seasonal export of carbon, nitrogen, and major solutes from Alaskan catchments with discontinuous permafrost, J. Geophys. Res.Biogeo., 111, G02020, https://doi.org/10.1029/2006JG000281, 2006.

Qiu, J.: The third pole, Nature, 454, 393-396, 2008.

Qu, B., Sillanpää, M., Li, C., Kang, S., Stubbins, A., Yan, F., Aho, K. S., Zhou, F., and Raymond, P. A.: Aged dissolved organic carbon exported from rivers of the Tibetan Plateau, PLoS One, 12, e0178166, https://doi.org/10.0171371/journal.pone.0178166, 2017.

Sato, T. and Kimura, F.: How does the Tibetan Plateau affect the transition of Indian monsoon rainfall?, Mon. Weather Rev., 135, 2006-2015, 2007.

Schuur, E. A. G., McGuire, A. D., Schadel, C., Grosse, G., Harden, J. W., Hayes, D. J., Hugelius, G., Koven, C. D., Kuhry, P., Lawrence, D. M., Natali, S. M., Olefeldt, D., Romanovsky, V. E., Schaefer, K., Turetsky, M. R., Treat, C. C., and Vonk, J. E.: Climate change and the permafrost carbon feedback, Nature, 520, 171-179, 2015.

Selvam, B. P., Lapierre, J.-F., Guillemette, F., Voigt, C., Lamprecht, R. E., Biasi, C., Christensen, T. R., Martikainen, P. J., and Berggren, M.: Degradation potentials of dissolved organic carbon (DOC) from thawed permafrost peat, Sci. Rep., 7, 45811, https://doi.org/10.1038/srep45811, 2017. 
Spencer, R. G. M., Aiken, G. R., Wickland, K. P., Striegl, R. G., and Hernes, P. J.: Seasonal and spatial variability in dissolved organic matter quantity and composition from the Yukon River basin, Alaska, Global Biogeochem. Cy., 22, GB4002, https://doi.org/10.1029/2008GB003231, 2008.

Spencer, R. G. M., Aiken, G. R., Butler, K. D., Dornblaser, M. M., Striegl, R. G., and Hernes, P. J.: Utilizing chromophoric dissolved organic matter measurements to derive export and reactivity of dissolved organic carbon exported to the Arctic Ocean: a case study of the Yukon River, Alaska, Geophys. Res. Lett., 36, 141-153, 2009.

Spencer, R. G. M., Guo, W., Raymond, P. A., Dittmar, T., Hood, E., Fellman, J., and Stubbins, A.: Source and biolability of ancient dissolved organic matter in glacier and lake ecosystems on the Tibetan Plateau, Geochim. Cosmochim. Ac., 142, 64-74, 2014.

Stenson, A. C., Marshall, A. G., and Cooper, W. T.: Exact masses and chemical formulas of individual Suwannee River fulvic acids from ultrahigh resolution electrospray ionization Fourier transform ion cyclotron resonance mass spectra, Anal. Chem., 75, 1275-1284, 2003.

Striegl, R. G., Dornblaser, M. M., Aiken, G. R., Wickland, K. P., and Raymond, P. A.: Carbon export and cycling by the Yukon, Tanana, and Porcupine rivers, Alaska, 2001-2005, Water Resour. Res., 43, W02411, https://doi.org/10.1029/2006WR005201, 2007

Stubbins, A. and Dittmar, T.: Illuminating the deep: Molecular signatures of photochemical alteration of dissolved organic matter from North Atlantic Deep Water, Mar. Chem., 177, 318-324, 2015

Stubbins, A., Mann, P. J., Powers, L., Bittar, T. B., Dittmar, T., McIntyre, C. P., Eglinton, T. I., Zimov, N., and Spencer, R. G. M.: Low photolability of yedoma permafrost dissolved organic carbon, J. Geophys. Res.-Biogeo., 122, 200-211, 2017.

Stubbins, A., Spencer, R. G. M., Chen, H. M., Hatcher, P. G., Mopper, K., Hernes, P. J., Mwamba, V. L., Mangangu, A. M., Wabakanghanzi, J. N., and Six, J.: Illuminated darkness: Molecular signatures of Congo River dissolved organic matter and its photochemical alteration as revealed by ultrahigh precision mass spectrometry, Limnol. Oceanogr., 55, 1467-1477, 2010.

Stuiver, M. and Reimer, P. J.: Extended ${ }^{14} \mathrm{C}$ Data Base and Revised Calib 3. $0{ }^{14} \mathrm{C}$ Age Calibration Program, Radiocarbon, 35, 215 230, 1993.

Tarnocai, C., Canadell, J. G., Schuur, E. A. G., Kuhry, P., Mazhitova, G., and Zimov, S.: Soil organic carbon pools in the northern circumpolar permafrost region, Global Biogeochem. Cy., 23, GB2023, https://doi.org/10.1029/2008gb003327, 2009.

Vonk, J. E., Mann, P. J., Davydov, S., Davydova, A., Spencer, R. G. M., Schade, J., Sobczak, W. V., Zimov, N., Zimov, S., Bulygina, E., Eglinton, T. I., and Holmes, R. M.: High biolability of ancient permafrost carbon upon thaw, Geophys. Res. Lett., 40, 2689 2693, 2013.

Vonk, J. E., Tank, S. E., Bowden, W. B., Laurion, I., Vincent, W. F., Alekseychik, P., Amyot, M., Billet, M. F., Canário, J., Cory, R. M., Deshpande, B. N., Helbig, M., Jammet, M., Karlsson, J., Larouche, J., MacMillan, G., Rautio, M., Walter Anthony, K. M., and Wickland, K. P.: Reviews and syntheses: Effects of permafrost thaw on Arctic aquatic ecosystems, Biogeosciences, 12, 7129-7167, https://doi.org/10.5194/bg-12-7129-2015, 2015.
Wang, B., Bao, Q., Hoskins, B., Wu, G., and Liu, Y.: Tibetan Plateau warming and precipitation changes in East Asia, Geophys. Res. Lett., 35, 63-72, 2008.

Wang, Y., Xu, Y., Spencer, R. G. M., Zito, P., Kellerman, A., Podgorski, D., Xiao, W., Wei, D., Rashid, H., and Yang, Y.: Selective leaching of dissolved organic matter from alpine permafrost soils on the Qinghai-Tibetan Plateau, J. Geophys. Res.-Biogeo., 123, 1005-1016, 2018.

Ward, C. P. and Cory, R. M.: Chemical composition of dissolved organic matter draining permafrost soils, Geochim. Cosmochim. Ac., 167, 63-79, 2015.

Ward, C. P. and Cory, R. M.: Complete and Partial Photo-oxidation of Dissolved Organic Matter Draining Permafrost Soils, Environ. Sci. Technol., 50, 3545-3553, 2016.

Weishaar, J. L., Aiken, G. R., Bergamaschi, B. A., Fram, M. S., Fujii, R., and Mopper, K.: Evaluation of specific ultraviolet absorbance as an indicator of the chemical composition and reactivity of dissolved organic carbon, Environ. Sci. Technol. 37, 47024708, 2003.

Wickland, K. P., Aiken, G. R., Butler, K., Dornblaser, M. M., Spencer, R. G. M., and Striegl, R. G.: Biodegradability of dissolved organic carbon in the Yukon River and its tributaries: Seasonality and importance of inorganic nitrogen, Global Biogeochem. Cy., 26, GB0E03, https://doi.org/10.1029/2012GB004342, 2012.

Wild, B., Schnecker, J., Alves, R. J. E., Barsukov, P., Bárta, J., Čapek, P., Gentsch, N., Gittel, A., Guggenberger, G., Lashchinskiy, N., Mikutta, R., Rusalimova, O., Šantrůčková, H., Shibistova, O., Urich, T., Watzka, M., Zrazhevskaya, G., and Richter, A.: Input of easily available organic $\mathrm{C}$ and $\mathrm{N}$ stimulates microbial decomposition of soil organic matter in arctic permafrost soil, Soil Biol. Biochem., 75, 143-151, 2014.

Wu, G., Liu, Y., Zhang, Q., Duan, A., Wang, T., Wan, R., Liu, X., Li, W., Wang, Z., and Liang, X.: The influence of mechanical and thermal forcing by the Tibetan Plateau on Asian climate, J. Hydrometeorol., 8, 770-789, 2007.

$\mathrm{Xu}, \mathrm{Y}$.: Permafrost carbon along alpine stream on the QinghaiTibet Plateau, https://doi.org//10.6084/m9.figshare.7301246.v1, last access: 7 November 2018.

Yao, T., Pu, J., Lu, A., Wang, Y., and Yu, W.: Recent glacial retreat and its impact on hydrological processes on the Tibetan Plateau, China, and surrounding regions, Arct. Antarct. Alp. Res., 39, 642-650, 2007.

Zhang, Z. Q. and Wu, Q.-B.: Predicting changes of active layer thickness on the Qinghai-Tibet Plateau as climate warming, J. Glaciol. Geocryol., 34, 505-511, 2012.

Zhu, X., Wang, W., and Fraedrich, K.: Future climate in the Tibetan Plateau from a statistical regional climate model, J. Clim., 26, 10125-10138, 2013.

Zimov, S. A., Schuur, E. A. G., and Chapin, F. S.: Permafrost and the global carbon budget, Science, 312, 1612-1613, 2006. 